\title{
Phenylalanyl-tRNA Ligase Beta Subunit
}

National Cancer Institute

\section{Source}

National Cancer Institute. Phenylalanyl-tRNA Ligase Beta Subunit. NCI Thesaurus. Code C29589.

Phenylalanine-tRNA ligase beta subunit (589 aa, $\sim 66 \mathrm{kDa}$ ) is encoded by the human FARSB gene. This protein plays a role in attaching L-phenylalanine to the terminal adenosine of the appropriate tRNA. 